\title{
KELIMPAHAN BAKTERI RIZOSFER PADA SISTEM PHT-BIOINTENSIF SERTA KEMAMPUAN ANTAGONISMENYA TERHADAP SCLEROTIUM ROLFSII PADA KEDELAI
}

\author{
Abdjad Asih Nawangsih, Tita Widjayanti, \& Yana Anisa \\ Departemen Proteksi Tanaman Fakultas Pertanian Institut Pertanian Bogor \\ Jl. Kamper Kampus IPB Dramaga Bogor, 16680 \\ E-mail: asnawangsih@yahoo.com
}

\begin{abstract}
Abundance of rhizospheric bacteria on the IPM-Biointensive system and their antagonistic activities toward Sclerotium rolfsii on soybean. Abundance of beneficial microorganisms in the soil is one of the active soil indicators the success of integrated pests management (IPM) system. Some beneficial groups of microorganisms can be used as biocontrol agents. This experiment was conducted to evaluate the effects of IPM-Biointensive by integrated application of resistant varieties, rice-straw mulch, and biocontrol agents on the abundance of rizospheric bacteria of soybean, also to evaluate the suppressiveness of the bacteria to the mycelial growth of $S$. rolfsii in vitro. Abundance of the bacteria was determined by isolation using serial dilution and plate-count techniques. Suppression to the fungus was evaluated using dual culture technique. Heat tolerant bacteria had the highest abundance (ranged $10^{11}-10^{12} \mathrm{cfu} / \mathrm{g}$ soil), followed by non-fluorescence bacteria $\left(10^{11} \mathrm{cfu} / \mathrm{g}\right.$ soil), chitinolytic bacteria $\left(10^{6}-10^{9} \mathrm{cfu} / \mathrm{g}\right.$ soil), and fluorescence bacteria with population range was $10^{3}-10^{8}$ cfu/g soil. Gepak kuning variety grown with application of rice-straw mulch and PGPR $\left(\mathrm{V}_{2} \mathrm{M}_{1} \mathrm{P}_{1}\right)$ caused the highest abundance of rizosphere bacteria. One of the heat tolerant bacteria, i.e. TP32, caused the highest suppression to the mycelial growth of S. rolfsii in vitro. Based on the morphology, physiology, and biochemical properties, the isolate was identified as Bacillus sp.
\end{abstract}

Key words: Anjasmoro, Bacillus subtilis, biological control, Gepak kuning, PGPR

\begin{abstract}
ABSTRAK
Kelimpahan bakteri rizosfer pada sistem PHT-Biointensif serta kemampuan antagonismenya terhadap Sclerotium rolfsii pada kedelai. Kelimpahan mikroorgnisme yang menguntungkan dalam tanah merupakan salah satu indikator tanah aktif yang menjadi salah satu indikator keberhasilan sistem pengendalian hama terpadu (PHT). Beberapa kelompok mikroorganisme terutama bakteri menguntungkan tersebut dapat dimanfaatkan sebagai agen biokontrol. Penelitian ini dilaksanakan dengan tujuan untuk mengevaluasi pengaruh aplikasi PHT-Biointensif dengan penggunaan varietas tahan, pemberian mulsa jerami dan aplikasi agen biokontrol secara terpadu terhadap kelimpahan bakteri rizosfer kedelai serta mengevaluasi kemampuan bakteri tersebut dalam menekan pertumbuhan miselia S. rolfsii secara in vitro. Penghitungan kelimpahan bakteri dilakukan dengan cara mengisolasi bakteri rizosfer tanaman kedelai dengan metode pengenceran berseri dan pencawanan (plate-count). Uji penekanan pertumbuhan miselia dilakukan dengan metode dual culture. Bakteri tahan panas memiliki kelimpahan paling tinggi dengan kisaran $10^{11}-10^{12} \mathrm{cfu} / \mathrm{g}$ tanah, diikuti dengan bakteri non-fluorescence dengan kelimpahan $10^{11} \mathrm{cfu} / \mathrm{g}$ tanah, bakteri kitinolitik dengan kisaran $10^{6}-10^{9} \mathrm{cfu} / \mathrm{g}$ tanah dan bakteri kelompok fluorescence dengan kelimpahan $10^{3}-10^{8} \mathrm{cfu} / \mathrm{g}$ tanah. Kelimpahan bakteri paling tinggi terjadi pada petak yang ditanami varietas Gepak Kuning dengan aplikasi mulsa jerami dan PGPR $\left(\mathrm{V}_{2} \mathrm{M}_{1} \mathrm{P}_{1}\right)$. Salah satu isolat bakteri rizosfer, yaitu TP32, mampu menekan pertumbuhan miselia S. rolfsii secara in vitro dengan persentase penghambatan paling tinggi hingga mencapai 95,6\%. Berdasarkan ciri-ciri morfologi, fisiologi dan biokimia, bakteri tersebut merupakan kelompok Bacillus sp.
\end{abstract}

Kata kunci: Anjasmoro, Bacillus subtilis, pengendalian biologi, Gepak kuning, PGPR

\section{PENDAHULUAN}

Indikator keberhasilan sistem PHT-Biointensif salah satunya adalah tanah aktif. Hal ini sangat berhubungan dengan kelimpahan bakteri yang menguntungkan dalam tanah. Banyak bakteri tanah yang telah diketahui mampu menghambat pertumbuhan patogen dan meningkatkan pertumbuhan tanaman diantaranya: kelompok bakteri kitinolitik, Bacillus sp., Pseudomonas fluorescens dan Actinomycetes (Baker \& Cook, 1983; Bolan, 1991).

Bakteri kitinolitik merupakan bakteri yang kompeten memproduksi enzim kitinase dan memanfaatkan kitinase untuk asimilasi kitin sebagai 
sumber karbon dan nitrogen (Wu et al., 2001). Kitinase dapat mendegradasi kitin yang merupakan komponen penting pada dinding sel cendawan, integumen serangga, dan kerangka luar golongan arthopoda, moluska, nematoda dan protozoa (Wang \& Chang, 1997).

Sudjono (1997) melaporkan bakteri kitinolitik Arthobacter sp. dan Hafnia sp. telah diketahui mampu mengendalikan Fusarium sp. dan Sclerotinia sp. pada tanaman tomat dan arbei. Genus bakteri yang telah banyak dilaporkan menghasilkan kitinase antara lain Aeromonas, Alteromonas, Chromobacterium, Enterobacter, Ewingella, Pseudo-alteromonas, Pseudomonas, Serratia dan Vibrio (Chernin et al., 1998). Beberapa spesies yang telah dipelajari antara lain Aeromonas sp, Bacillus cereus, B. licheformis (Pleban et al., 1997), Clostridium sp., Enterobacter liquefaciens, Flavobacterium indolthecium, Klebsiella sp., Micrococcus colpogenes, Pseudomonas sp., Serratia marcescens, Vibrio parahaemaluticus, V. alginolyticus, Bacillus dan Pyrococcus (Gao et al., 2003).

Selain bakteri kelompok kitinolitik, bakteri tanah lain yang diketahui mampu menghambat pertumbuhan patogen adalah bakteri tahan panas. Menurut Schaad (2001) bakteri tahan panas yang telah banyak diketahui adalah bakteri golongan Bacillus sp. Sebagian besar bakteri genus Bacillus sp. bersifat saprofitik. Bacillus sp. memiliki daya tahan hidup yang cukup tinggi khususnya terhadap suhu tinggi karena menghasilkan endospora tahan panas (Compant et al., 2005), sehingga sangat potensial digunakan sebagai agens pengendali hayati patogen tumbuhan. Peran Bacillus sp. sebagai agens pengendali hayati sangat bervariasi tergantung isolat antagonis, patogen dan lingkungannya (Arwiyanto et al., 1999). Wartono (2010) melaporkan B. subtilis efektif menekan perkembangan Xanthomonas oryzae pv. oryzae di lapangan serta efektif dalam meningkatkan bobot gabah kering di lapangan mencapai 69,2 g/rumpun.

Kelompok bakteri lain yang berpotensi sebagai agens hayati adalah bakteri $P$. fluorescens. Bakteri kelompok ini dicirikan dengan menghasilkan pigmen berwarna hijau kuning yang dapat digunakan untuk identifikasi serta klasifikasi yang berupa senyawa flourescence atau pyoverdin yang berpendar di bawah cahaya ultraviolet (panjang gelombang $266 \mathrm{~nm}$ ). Mariani (1995) telah berhasil mengisolasi 52 isolat bakteri dari daun kedelai, dan diperoleh 3 isolat masing-masing isolat B29, B30, dan B39 yang dinyatakan berpotensi untuk dikembangkan sebagai agens biokontrol. Mishra et al. (2011) melaporkan bahwa Pseudomonas kelompok fluorescence yang diaplikasikan secara tunggal maupun dikombinasikan dengan Trichoderma harzianum mampu menekan kejadian penyakit yang disebabkan oleh $S$. rolfsii di rumah kaca hingga 47,68\%.

\section{METODE PENELITIAN}

Waktu dan Tempat. Penelitian dilaksanakan di Laboratorium Bakteriologi Departemen Proteksi Tanaman, Fakultas Pertanian, Institut Pertanian Bogor, dan di lahan petani di Desa Ciburuy, Kecamatan Cigombong, Sukabumi. Lahan petani tersebut berada pada ketinggian $495 \mathrm{~m}$ dpl, $6^{\circ} \mathrm{LU}, 43^{\circ} \mathrm{LS}, 106^{\circ}, 48,32$ BT. Penelitian dilaksanakan pada bulan Agustus 2010 sampai Juni 2011.

Pengaruh Varietas Kedelai, Mulsa Jerami dan PGPR. Percobaan pengaruh varietas, mulsa jerami dan PGPR di lapangan dilakukan dalam Rancangan Acak Kelompok Faktorial yang terdiri dari 3 faktor perlakuan yaitu Varietas [Anjasmoro $\left(\mathrm{V}_{1}\right)$ dan Gepak Kuning $\left(\mathrm{V}_{2}\right)$ ]; Mulsa Jerami [Dengan mulsa jerami $\left(\mathbf{M}_{1}\right)$ dan Tanpa mulsa jerami $\left(\mathrm{M}_{2}\right)$ ]; PGPR [Dengan PGPR $\left(\mathrm{P}_{1}\right)$ dan Tanpa PGPR $\left.\left(\mathrm{P}_{2}\right)\right]$, masing-masing 2 taraf perlakuan, dan 3 kali ulangan.

Lahan percobaan yang terletak di Desa Ciburuy, Kecamatan Cigombong, Sukabumi, seluas $1344 \mathrm{~m}^{2}$ dibagi menjadi 24 petakan berukuran masing-masing 8 $\mathrm{x} 8 \mathrm{~m}$. Di dalam petak dibuat 8 guludan dengan ukuran $0,7 \times 8 \mathrm{~m}$ dan jarak antar guludan $0,3 \mathrm{~m}$. Tiap guludan dibuat 2 baris tanaman dengan jarak $40 \mathrm{~cm}$.

Varietas kedelai (Anjasmoro dan Gepak Kuning) sebagai faktor perlakuan pertama masing-masing ditanam dengan jarak tanam $20 \times 20 \mathrm{~cm}$. Setiap lubang tanam diisi 2 butir benih. Di samping guludan dibuat parit kecil untuk alur pupuk NPK dengan komposisi 1:1:1. Pemberian mulsa jerami padi sebagai faktor perlakuan kedua dilakukan setelah penanaman. Jerami dipasang menutupi seluruh permukaan tanah. Perlakuan biokontrol yang merupakan formulasi antara bakteri $B$. subtilis $\mathrm{AB}$ 89 dan P. fluorescens RH4003 (Nawangsih 2006) diberikan 2 minggu setelah tanam. Formulasi dibuat dari biakan B. subtilis AB89 dan P. fluorescens $\mathrm{RH} 4003$ yang dipanen kemudian disuspensikan kedalam $1000 \mathrm{ml}$ medium LB, dihomogenkan dengan inkubator bergoyang selama 24 jam. Aplikasi dilakukan dengan cara menyiramkan $50 \mathrm{ml}$ suspensi (konsentrasi $10^{7}-10^{8} \mathrm{cfu} /$ ml) di sekitar perakaran tanaman kedelai.

Kelimpahan Bakteri Kitinolitik, Tahan Panas dan Fluorescence. Tanah diambil dari rizosfer tanaman sampel pada lahan percobaan dengan kedalaman \pm 10 $\mathrm{cm}$. Pengambilan dilakukan menggunakan metode pengambilan sampel huruf S (Gambar 1). Sampel tanah 
diambil saat tanaman berumur 6 minggu setelah tanam (MST) pada fase pembungaan. Pengambilan sampel tanah dilakukan untuk mengetahui kelimpahan dan keragaman bakteri kitinolitik, tahan panas, dan kelompok fluorescence.

Isolasi bakteri untuk penghitungan kelimpahan bakteri kitinolitik, tahan panas, dan kelompok flourescence dilakukan dengan teknik pengenceran dan pencawanan. Sebanyak $20 \mathrm{~g}$ tanah perakaran diambil dari masing-masing 10 tanaman sampel secara acak dari setiap perlakuan. Sampel tersebut kemudian disatukan dan sebanyak $10 \mathrm{~g}$ diambil untuk selanjutnya disuspensikan dalam $90 \mathrm{ml}$ akuades steril. Setelah dilakukan pengenceran berseri, sebanyak $0,1 \mathrm{ml}(100$ $\mu \mathrm{l})$ dari masing-masing pengenceran disebar (platting) dengan menggunakan glass beads (diameter $0,5 \mathrm{~mm}$ ) pada media kitin (meat extract $10 \mathrm{~g} / \mathrm{l}$, peptone $10 \mathrm{~g} / \mathrm{l}$, $\mathrm{NaCl} 1,5 \mathrm{~g} / \mathrm{l}$, Agar $15 \mathrm{~g} / \mathrm{l}$, ditambah dengan 0,2\% koloidal kitin) untuk mengisolasi bakteri kitinolitik, media KBA (proteose peptone 20g/l, glycerol $10 \mathrm{~g} / \mathrm{l}, \mathrm{K}_{2} \mathrm{HPO}_{4} 1,5 \mathrm{~g} /$ $1, \mathrm{MgSO}_{4} \cdot 7 \mathrm{H}_{2} \mathrm{O} 1,5 \mathrm{~g} / \mathrm{l}$, agar $20 \mathrm{~g} / 1, \mathrm{pH} 7,2$ ) untuk mengisolasi bakteri kelompok flourescence dan media TSA (pancreatic digest of casein $15 \mathrm{~g} / \mathrm{l}$, papaic digest of soybean meal $5 \mathrm{~g} / \mathrm{l}, \mathrm{NaCl} 5 \mathrm{~g} / \mathrm{l}$, agar $15 \mathrm{~g} / \mathrm{l}, \mathrm{pH} 7,3$ ) untuk mengisolasi bakteri tahan panas. Media dibuat berdasarkan formula yang ditulis oleh Atlas (2005). Khusus untuk media TSA, pencawanan dilakukan setelah suspensi sampel tanah dipanaskan pada suhu $80^{\circ} \mathrm{C}$ (15 menit). Media cawan yang sudah diinokulasi kemudian diinkubasikan pada suhu ruang $\left(28^{\circ} \mathrm{C}\right)$ selama 2 hari dan dihitung jumlah koloni serta jenis bakteri yang tumbuh.

Karakterisasi Isolat Bakteri Rizosfer. Karakterisasi isolat bakteri rizosfer secara umum dilakukan berdasarkan metode yang dikemukakan oleh Schaad (2001). Karakterisasi yang dilakukan meliputi morfologi koloni (bentuk, warna, elevasi), reaksi Gram, Reaksi Hipersensitif (HR), fluoresensi, hidrolisa kitin (sangat kuat : diameter zona bening $>2 \mathrm{~cm}$, kuat : diameter zona bening 1,5-2 cm, sedang: diameter zona bening 0,5$1,5 \mathrm{~cm}$, rendah: diameter zona bening $<0,5 \mathrm{~cm}$ ), pembentukan endospora, hemolisis darah (Yeh et al., 2009), dan uji LOPAT (Levan, Oksidase, Potato Soft Rot, Arginine, Tobacco Hypersensitive) (Schaad, 2001).

\section{Uji Penghambatan Miselia Sclerotium rolfsii oleh} Bakteri Rizosfer Kedelai. Inokulum cendawan $S$. rolfsii yang digunakan merupakan hasil isolasi dari tanaman kedelai yang terserang patogen tersebut. Uji penghambatan dilakukan dengan cara menumbuhkan patogen dan kandidat agen biokontrol dalam satu cawan Petri berisi media PDA. Potongan agar berdiameter $0,5 \mathrm{~cm}$ yang sudah ditumbuhi miselia cendawan diletakkan pada permukaan media PDA dalam cawan Petri berdiameter $9 \mathrm{~cm}$ dengan jarak $\pm 3 \mathrm{~cm}$ dari tepi cawan. Selanjutnya satu loop bakteri rizosfer atau akuades steril (sebagai kontrol) digoreskan berseberangan dengan cendawan dengan jarak $\pm 3 \mathrm{~cm}$ (Gambar 2). Persentase penghambatan dihitung dengan rumus yang dilaporkan oleh Ganesan et al. (2007) dengan modifikasi:

$$
\mathrm{IH}=\frac{\mathrm{R} 1-\mathrm{R} 2}{\mathrm{R} 1} \times 100 \%
$$

$\mathrm{R} 1$ = lebar miselia $S$. rolfsii ke arah goresan aquades steril (kontrol)

R2 = lebar miselia $S$. rolfsii ke arah bakteri rizosfer

Percobaan in vitro dilakukan dengan menggunakan Rancangan Acak Lengkap dengan 3 ulangan. Data yang diperoleh dianalisis menggunakan SAS versi 9.1.3. Perlakuan yang berbeda nyata diuji

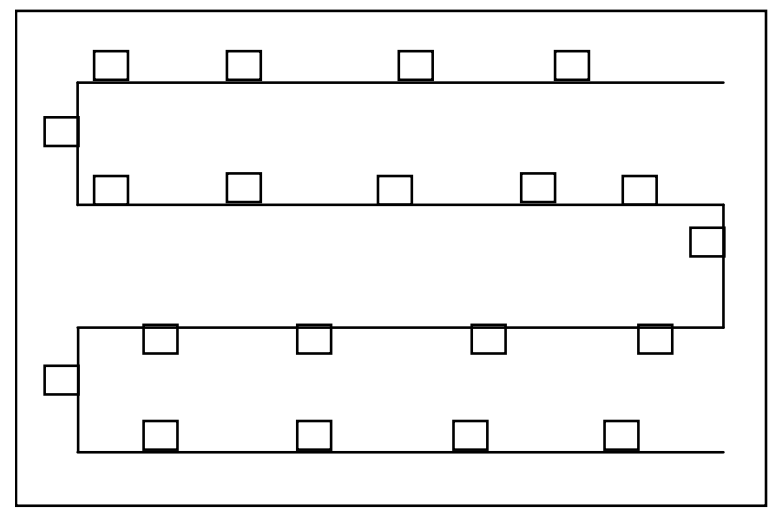

Gambar 1. Metode pengambilan sampel dengan pola S 


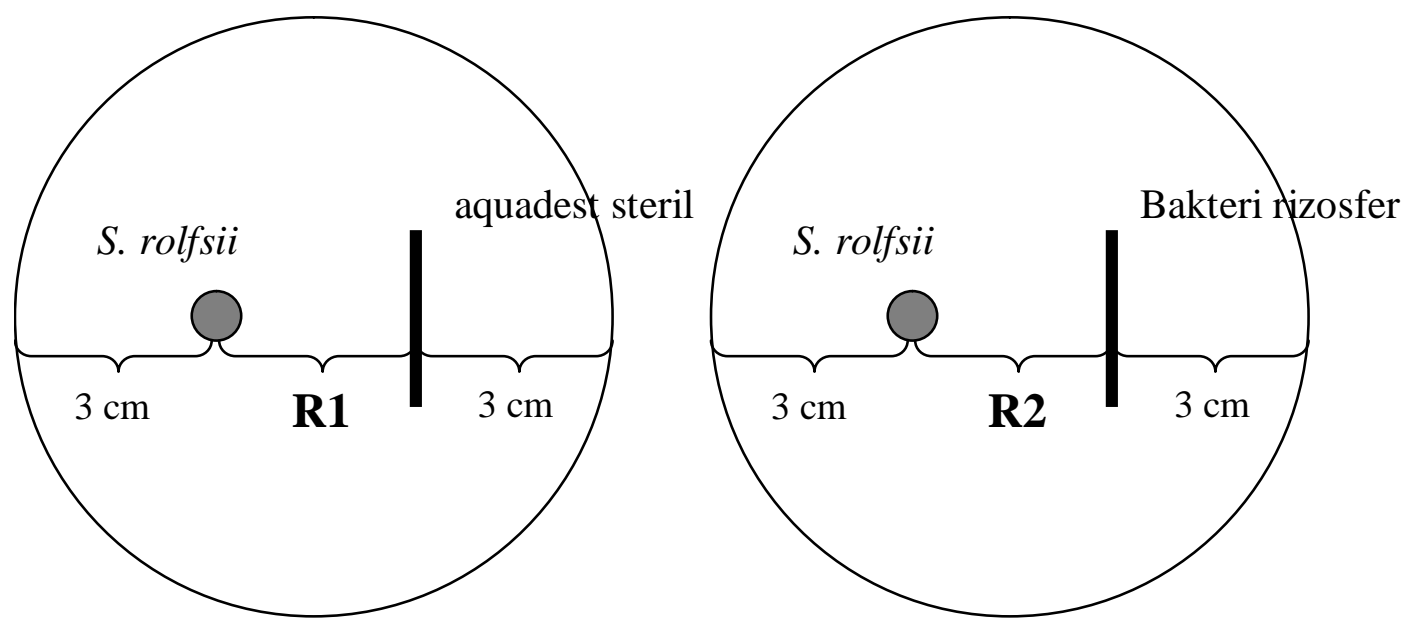

Gambar 2. Tata letak cendawan patogen dan bakteri rizosfer dalam pengujian penghambatan melalui mekanisme antibiosis

lanjut dengn uji selang berganda Duncan pada taraf nyata $5 \%$.

\section{HASIL DAN PEMBAHASAN}

Kelimpahan Bakteri Rizosfer. Kelimpahan empat kelompok bakteri yang diamati pada masing-masing perlakuan percobaan sistem PHT-biointensif disajikan dalam Gambar 3. Pada gambar tersebut terlihat bahwa pada masing-masing perlakuan, bakteri tahan panas memiliki kelimpahan paling tinggi dengan kisaran $10^{11}$ $10^{12} \mathrm{cfu} / \mathrm{g}$ tanah, diikuti dengan bakteri non-fluorescence dengan kelimpahan $10^{11} \mathrm{cfu} / \mathrm{g}$ tanah, bakteri kitinolitik dengan kisaran $10^{6}-10^{9} \mathrm{cfu} / \mathrm{g}$ tanah dan bakteri kelompok fluorescence dengan kelimpahan $10^{3}-10^{8} \mathrm{cfu} / \mathrm{g}$ tanah.

Kombinasi perlakuan varietas, mulsa jerami dan aplikasi PGPR mampu meningkatkan kelimpahan bakteri rizosfer kelompok kitinolitik, tahan panas, fluorescence dan non-fluorescence dibandingkan dengan perlakuan kontrol. Menurut Graham (2005), keseimbangan biologi pada rizosfer untuk mengendalikan patogen dapat diciptakan dengan memanipulasi lingkungan yaitu dengan cara integrasi pengendalian hayati dan kultur teknis.

Kombinasi perlakuan varietas Gepak Kuning dengan mulsa jerami dan dengan aplikasi PGPR $\left(\mathrm{V}_{2} \mathrm{M}_{1} \mathrm{P}_{1}\right)$ menunjukkan nilai kelimpahan bakteri terbesar hampir pada semua kelompok bakteri (Gambar 3). Selain itu diketahui juga bahwa keragaman kelompok bakteri terbanyak terdapat pada kombinasi perlakuan Gepak Kuning yang diberi mulsa jerami dan diaplikasikan PGPR $\left(\mathrm{V}_{2} \mathrm{M}_{1} \mathrm{P}_{1}\right)($ Tabel 1). Semakin beragam mikroorganisme dalam tanah maka akan semakin banyak peluang mengendalikan patogen secara biologi.

Hasil isolasi tanah menunjukkan bahwa kelimpahan bakteri rizosfer (kitinolitik, tahan panas,

$\mathbf{A}$

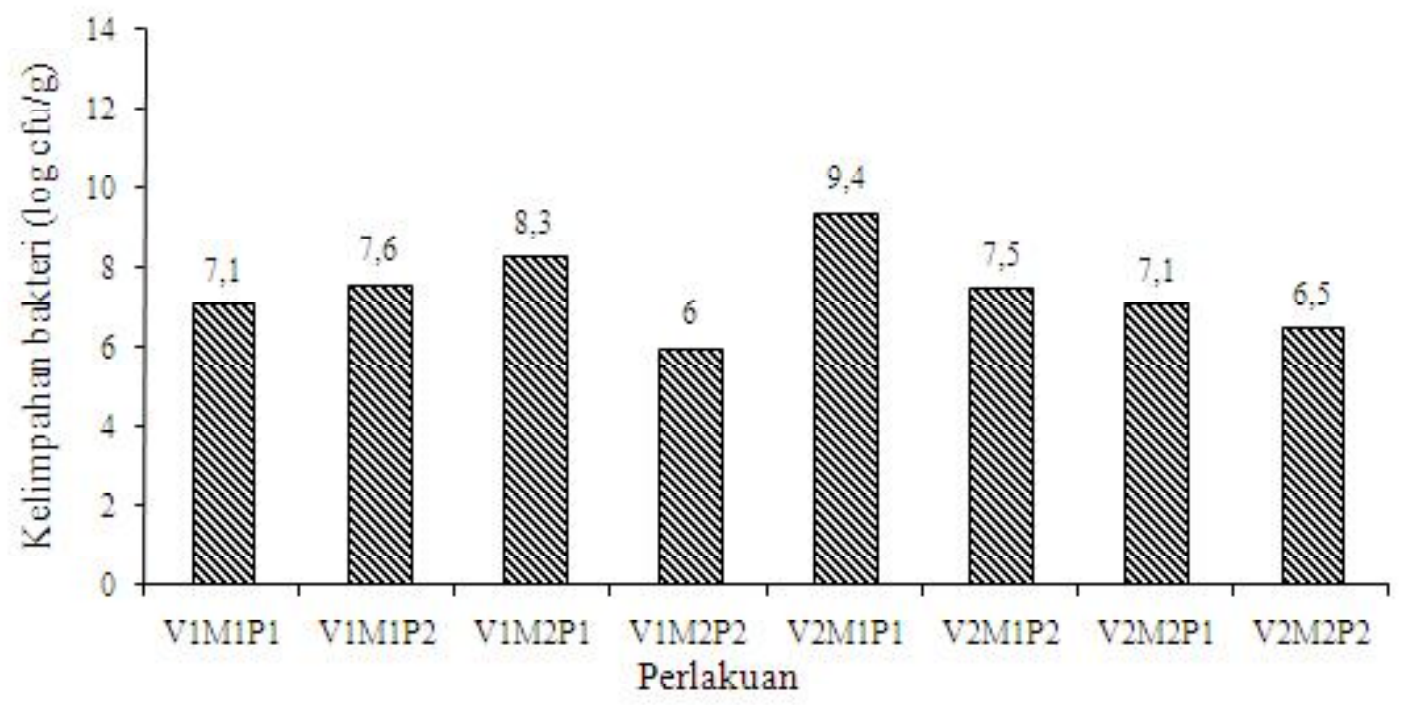


B

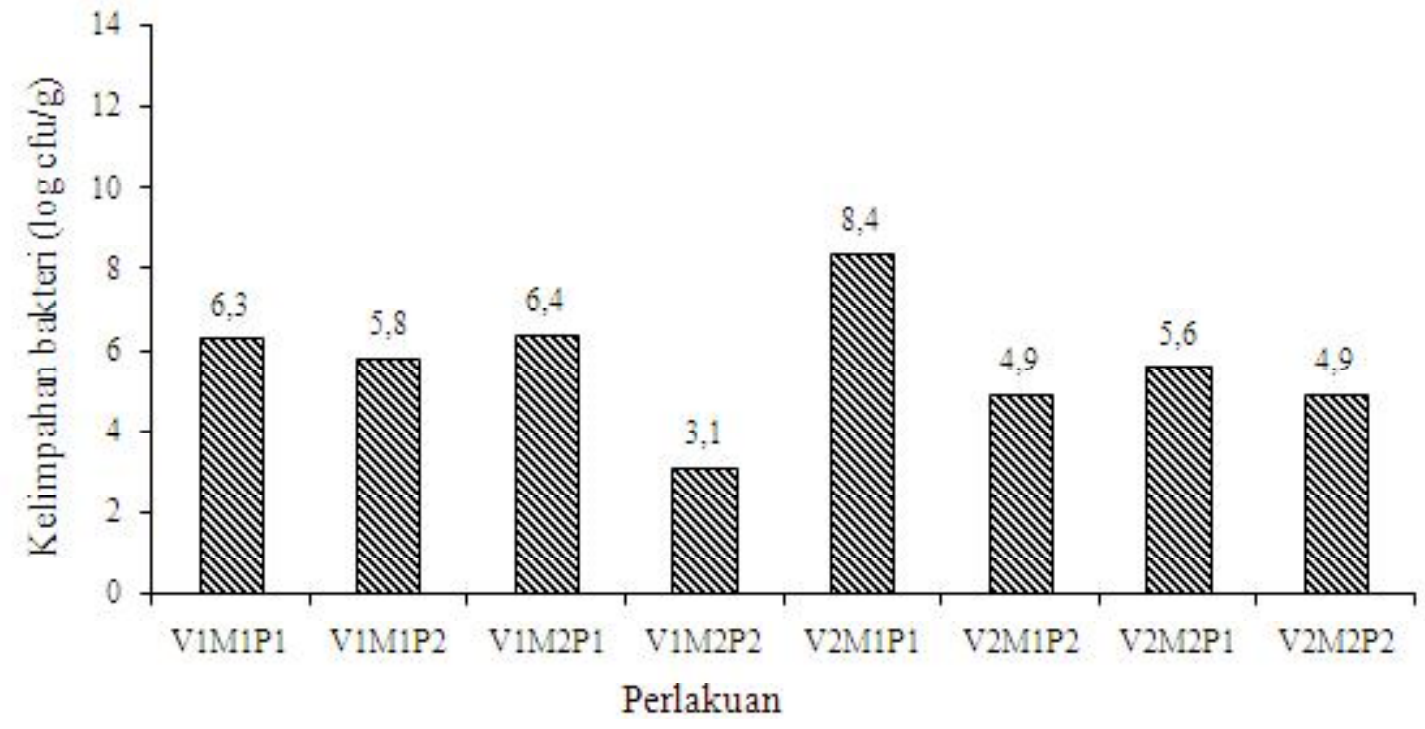

C



Perlakuan

D



Gambar 3. Diagram kelimpahan masing-masing kelompok bakteri pada kombinasi perlakuan dibandingkan dengan kontrol pada masing-masing varietas; $\mathrm{A}=$ Bakteri kitinolitik, $\mathrm{B}=$ Bakteri fluoresence, $\mathrm{C}=$ Bakteri tahan panas, $\mathrm{D}=$ Bakteri non-fluorescence; $\mathrm{V}_{1}=$ varietas Anjasmoro, $\mathrm{V}_{2}=$ varietas Gepak Kuning; $\mathrm{M}_{1}=$ dengan mulsa jerami; $\mathrm{M}_{2=}$ tanpa mulsa jerami; $\mathrm{P}_{1}=$ dengan $\mathrm{PGPR} ; \mathrm{P}_{2}=$ tanpa $\mathrm{PGPR}$. 
fluorescence dan non-fluorescence) pada petak yang diberi mulsa jerami tidak berbeda dengan tanpa mulsa jerami. Oke \& Ologun (2005) menyatakan bahwa mulsa merupakan sumber energi bagi mikroorganisme yang hidup di dalam tanah yang selanjutnya akan didekomposisi dari senyawa kompleks menjadi senyawa sederhana. Sehingga, hasil dekomposisi dapat dimanfaatkan langsung oleh tanaman. Dalam penelitian ini ternyata hasilnya berbeda, kemungkinan jerami yang digunakan masih belum terdekomposisi secara menyeluruh sehingga belum dapat dimanfaatkan oleh bakteri yang ada.

Aktivitas Penghambatan Bakteri Rizosfer terhadap $S$. rolfsii . Persentase penghambatan miselia $S$. rolfsii oleh masing-masing isolat bakteri rizosfer kedelai disajikan dalam Tabel 2, sedangkan contoh bentuk penghambatan disajikan dalam Gambar 4. Pada masing-masing kelompok bakteri ditemukan satu isolat yang menghasilkan persentase penghambatan tertinggi. Untuk kelompok bakteri tahan panas (TP), bakteri nonfluorescence (NF), bakteri kitinolitik (KT) dan bakteri fluorescence $(\mathrm{F})$, penghambatan tertinggi masingmasing dihasilkan oleh isolat TP32 $(95,6 \%)$, NF10 $(85,8 \%)$, KT4 $(80,5 \%)$ dan F8 $(45,0 \%)$. Secara keseluruhan, isolat bakteri tahan panas TP32 mampu menghasilkan persentase penghambatan tertinggi. Paramageetham \& Babu (2012) melaporkan bahwa bakteri Pseudomonas kelompok fluorescence isolat PSTPT 13 yang diisolasi dari hutan mampu menghambat pertumbuhan $S$. rolfsii in vitro hingga $75 \%$ dengan memproduksi HCN, siderofor dan enzim protease. Nilai tersebut lebih tinggi dibandingkan dengan kemampuan isolat bakteri kelompok fluorescence yang berhasil diisolasi dalam penelitian ini.

\section{Karakterisasi Beberapa Isolat Terpilih}

Bakteri Tahan Panas. Berdasarkan perbedaan morfologi koloni, lima isolat bakteri tahan panas yang paling banyak ditemukan saat isolasi adalah TP31, TP42, TP48, TP61 dan TP70, yang selanjutnya diuji pembentukan sporanya. Hasil pengujian produksi endospora terhadap isolat-isolat tersebut disajikan dalam Tabel 3.

Menurut Pelczar \& Chan (1986), endospora berfungsi sebagai struktur bertahan. Dibandingkan dengan sel vegetatif, endospora sangat resisten terhadap kondisi-kondisi fisik yang kurang menguntungkan seperti suhu tinggi dan kekeringan juga terhadap bahan-bahan kimia seperti desinfektan. Hasil pengamatan diketahui posisi endospora dapat terletak ditengah dan didekat ujung sel. Menurut Salle (1973), masing-masing spesies Bacillus memiliki karakteristik tersendiri baik ukuran, bentuk dan posisi spora walaupun variasi ini bisa berubah dalam lingkungan yang berbeda.

Berdasarkan hasil pengujian karakter hemolisis diketahui bahwa $B$. subtilis AB89 menunjukkan reaksi lisis yang bersifat $\beta$-hemolisis (Gambar 4) dan 3 isolat lain yang menunjukkan reaksi yang sama dengan B. subtilis AB89 yaitu isolat TP42, TP48 dan TP70 (Tabel 4). Yeh et al. (2009) menyatakan bahwa ada tiga tipe hemolisis, yaitu: (1) Alfa hemolisis ( $\alpha$-hemolisis) yang artinya terjadi lisis parsial sehingga media di sekeliling koloni berwarna abu-abu kehijauan, (2) Beta hemolisis ( $\beta$-hemolisis) yang artinya darah secara lengkap dilisis oleh mikroba sehingga media di sekeliling koloni menjadi tidak berwarna atau bening, dan (3) Gamma hemolisis ( $\gamma$-hemolisis) yang artinya tidak terjadi lisis oleh mikroba sehingga tidak terjadi perubahan warna pada media.

Tabel 1. Pengaruh varietas, mulsa jerami dan aplikasi PGPR terhadap keanekaragaman bakteri rizosfer (kelompok kitinolitik, tahan panas, non-fluorescence dan fluorescence)

\begin{tabular}{|c|c|c|c|c|c|}
\hline \multirow{2}{*}{ Perlakuan } & \multicolumn{4}{|c|}{ Jumlah jenis bakteri } & \multirow{2}{*}{ Total } \\
\hline & Tahan panas & Kitinolitik & Fluorescence & Non-fluorescence & \\
\hline $\mathrm{V}_{1} \mathrm{M}_{1} \mathrm{P}_{1}$ & 15 & 3 & 1 & 10 & 29 \\
\hline $\mathrm{V}_{1} \mathrm{M}_{1} \mathrm{P}_{2}$ & 5 & 7 & 1 & 9 & 22 \\
\hline $\mathrm{V}_{2} \mathrm{M}_{1} \mathrm{P}_{1}$ & 20 & 12 & 3 & 14 & 49 \\
\hline $\mathrm{V}_{2} \mathrm{M}_{1} \mathrm{P}_{2}$ & 7 & 19 & 1 & 11 & 38 \\
\hline $\mathrm{V}_{1} \mathrm{M}_{2} \mathrm{P}_{1}$ & 4 & 7 & 1 & 4 & 16 \\
\hline $\mathrm{V}_{1} \mathrm{M}_{2} \mathrm{P}_{2}$ & 10 & 9 & 2 & 3 & 24 \\
\hline $\mathrm{V}_{2} \mathrm{M}_{2} \mathrm{P}_{1}$ & 6 & 6 & 1 & 6 & 19 \\
\hline $\mathrm{V}_{2} \mathrm{M}_{2} \mathrm{P}_{2}$ & 4 & 3 & 1 & 6 & 14 \\
\hline
\end{tabular}

$\mathrm{V}_{1}$ : varietas Anjasmoro; $\mathrm{V}_{2}$ : varietas Gepak Kuning; $\mathrm{M}_{1}$ : dengan mulsa jerami; $\mathrm{M}_{2}$ :tanpa mulsa jerami; $\mathrm{P}_{1}$ : dengan PGPR; $\mathrm{P}_{2}$ : tanpa PGPR 
Tabel 2. Rerata persentase penghambatan isolat-isolat bakteri tahan panas, non-fluorescence, kitinolitik dan fluorescence terhadap $S$. rolfsii secara in vitro

\begin{tabular}{|c|c|c|c|c|c|c|c|c|}
\hline \multirow{3}{*}{ No. } & \multicolumn{8}{|c|}{ Penghambatan terhadap S. rolfsii ${ }^{*}$} \\
\hline & \multicolumn{2}{|c|}{$\begin{array}{l}\text { Bakteri tahan panas } \\
\text { (TP) }\end{array}$} & \multicolumn{2}{|c|}{$\begin{array}{c}\text { Bakteri non- } \\
\text { fluorescence (NF) }\end{array}$} & \multicolumn{2}{|c|}{$\begin{array}{c}\text { Bakteri kitinolitik } \\
(\mathrm{KT})\end{array}$} & \multicolumn{2}{|c|}{$\begin{array}{l}\text { Bakteri fluorescence } \\
(\mathrm{F})\end{array}$} \\
\hline & $\begin{array}{l}\text { Kode } \\
\text { isolat }\end{array}$ & $\%$ & $\begin{array}{l}\text { Kode } \\
\text { isolat }\end{array}$ & $\%$ & $\begin{array}{l}\text { Kode } \\
\text { isolat }\end{array}$ & $\%$ & $\begin{array}{l}\text { Kode } \\
\text { isolat }\end{array}$ & $\%$ \\
\hline 1 & TP1 & $63,4 \mathrm{ab}$ & NF1 & $60,0 \mathrm{ab}$ & KT1 & $50,4 \mathrm{~b}$ a & F1 & $28,5 \mathrm{ab}$ \\
\hline 2 & TP2 & $60,4 \mathrm{ab}$ & NF2 & $30,0 \mathrm{ab}$ & KT2 & $60,0 \mathrm{ab}$ & $\mathrm{F} 2$ & $36,6 \mathrm{ab}$ \\
\hline 3 & TP3 & $75,5 \mathrm{ab}$ & NF3 & $60,0 \mathrm{ab}$ & KT3 & $55,3 \mathrm{ab}$ & F3 & $37,5 \mathrm{ab}$ \\
\hline 4 & TP4 & $66,2 \mathrm{ab}$ & NF4 & $30,0 \mathrm{ab}$ & KT4 & 80,5 a & F4 & $36,8 \mathrm{ab}$ \\
\hline 5 & TP5 & $76,6 \mathrm{ab}$ & NF5 & $26,6 \mathrm{ab}$ & KT5 & $60,3 \mathrm{ab}$ & F5 & $41,0 \mathrm{ab}$ \\
\hline 6 & TP6 & $60,0 \mathrm{ab}$ & NF6 & $40,4 \mathrm{ab}$ & KT6 & $55,5 \mathrm{ab}$ & F6 & $37,5 \mathrm{ab}$ \\
\hline 7 & TP7 & $75,0 \mathrm{ab}$ & NF7 & $65,5 \mathrm{ab}$ & KT7 & $60,6 \mathrm{ab}$ & F7 & $34,7 \mathrm{ab}$ \\
\hline 8 & TP8 & $66,5 \mathrm{ab}$ & NF8 & $45,0 \mathrm{ab}$ & KT8 & $50,0 \mathrm{ab}$ & F8 & 45,0 a \\
\hline 9 & TP9 & $25,5 \mathrm{~b}$ & NF9 & $75,5 \mathrm{ab}$ & KT9 & $51,0 \mathrm{ab}$ & F9 & $18,0 \mathrm{ab}$ \\
\hline 10 & TP10 & $45,3 \mathrm{ab}$ & NF10 & 85,8 a & KT10 & $50,5 \mathrm{ab}$ & F10 & $34,5 \mathrm{ab}$ \\
\hline 11 & TP11 & $35,9 \mathrm{ab}$ & NF11 & $80,5 \mathrm{ab}$ & KT11 & $34,0 \mathrm{ab}$ & $\mathrm{K}$ & $0,0 \mathrm{~b}$ \\
\hline 12 & TP12 & $55,3 \mathrm{ab}$ & NF12 & $75,0 \mathrm{ab}$ & KT12 & $31,5 \mathrm{ab}$ & - & - \\
\hline 13 & TP13 & $40,5 \mathrm{ab}$ & NF13 & $25,9 \mathrm{ab}$ & KT13 & $31,2 \mathrm{ab}$ & - & - \\
\hline 14 & TP14 & $35,8 \mathrm{ab}$ & NF14 & $35,0 \mathrm{ab}$ & KT14 & $32,3 \mathrm{ab}$ & - & - \\
\hline 15 & TP15 & $50,4 \mathrm{ab}$ & NF15 & $60,3 \mathrm{ab}$ & KT15 & $80,0 \mathrm{ab}$ & - & - \\
\hline 16 & TP16 & $30,5 \mathrm{ab}$ & NF16 & $75,4 \mathrm{ab}$ & KT16 & $50,0 \mathrm{ab}$ & - & - \\
\hline 17 & TP17 & $46,6 \mathrm{ab}$ & NF17 & $40,3 \mathrm{ab}$ & KT17 & $33,2 \mathrm{ab}$ & - & - \\
\hline 18 & TP18 & $55,0 \mathrm{ab}$ & NF18 & $35,5 \mathrm{ab}$ & KT18 & $30,9 \mathrm{ab}$ & - & - \\
\hline 19 & TP19 & $90,3 \mathrm{ab}$ & NF19 & $60,5 \mathrm{ab}$ & KT19 & $40,1 \mathrm{ab}$ & - & - \\
\hline 20 & TP20 & $65,9 \mathrm{ab}$ & NF20 & $25,7 \mathrm{ab}$ & KT20 & $70,0 \mathrm{ab}$ & - & - \\
\hline 21 & TP21 & $80,0 \mathrm{ab}$ & $\mathrm{K}$ & $0,0 \mathrm{~b}$ & KT21 & $31,4 \mathrm{ab}$ & - & - \\
\hline 22 & TP22 & $65,3 \mathrm{ab}$ & - & - & $\mathrm{K}$ & $0,0 \mathrm{~b}$ & - & - \\
\hline 23 & TP23 & $45,5 \mathrm{ab}$ & - & - & - & - & - & - \\
\hline 24 & TP24 & $40,5 \mathrm{ab}$ & - & - & - & - & - & - \\
\hline 25 & TP25 & $60,6 \mathrm{ab}$ & - & - & - & - & - & - \\
\hline 26 & TP26 & $75,0 \mathrm{ab}$ & - & - & - & - & - & - \\
\hline 27 & TP27 & $75,0 \mathrm{ab}$ & - & - & - & - & - & - \\
\hline 28 & TP28 & $75,4 \mathrm{ab}$ & - & - & - & - & - & - \\
\hline 29 & ТP29 & $70,5 \mathrm{ab}$ & - & - & - & - & - & - \\
\hline 30 & TP30 & $45,4 \mathrm{ab}$ & - & - & - & - & - & - \\
\hline 31 & TP31 & $45,4 \mathrm{ab}$ & - & - & - & - & - & - \\
\hline 32 & TP32 & 95,6 a & - & - & - & - & - & - \\
\hline 33 & TP33 & $60,0 \mathrm{ab}$ & - & - & - & - & - & - \\
\hline 34 & TP34 & $85,0 a b$ & - & - & - & - & - & - \\
\hline 35 & TP35 & $85,0 \mathrm{ab}$ & - & - & - & - & - & - \\
\hline 36 & TP36 & $65,0 \mathrm{ab}$ & - & - & - & - & - & - \\
\hline 37 & TP37 & $85,0 \mathrm{ab}$ & - & - & - & - & - & - \\
\hline 38 & TP38 & $40,0 \mathrm{ab}$ & - & - & - & - & - & - \\
\hline 39 & TP39 & $75,0 \mathrm{ab}$ & - & - & - & - & - & - \\
\hline 40 & TP40 & $80,0 \mathrm{ab}$ & - & - & - & - & - & - \\
\hline 41 & TP41 & $75,0 \mathrm{ab}$ & - & - & - & - & - & - \\
\hline 42 & TP42 & $55,8 \mathrm{ab}$ & - & - & - & - & - & - \\
\hline
\end{tabular}


Tabel 2. lanjutan

\begin{tabular}{|c|c|c|c|c|c|c|c|c|}
\hline \multirow{3}{*}{ No. } & \multirow{2}{*}{\multicolumn{2}{|c|}{$\begin{array}{l}\text { Bakteri tahan panas } \\
(\mathrm{TP})\end{array}$}} & \multicolumn{4}{|c|}{ Penghambatan terhadap S. rolfsii $\left.{ }^{*}\right)$} & & \\
\hline & & & \multicolumn{2}{|c|}{$\begin{array}{c}\text { Bakteri non- } \\
\text { fluorescence (NF) }\end{array}$} & \multicolumn{2}{|c|}{$\begin{array}{c}\text { Bakteri kitinolitik } \\
(\mathrm{KT})\end{array}$} & \multicolumn{2}{|c|}{$\begin{array}{l}\text { Bakteri fluorescence } \\
(\mathrm{F})\end{array}$} \\
\hline & $\begin{array}{l}\text { Kode } \\
\text { isolat }\end{array}$ & $\%$ & $\begin{array}{l}\text { Kode } \\
\text { isolat }\end{array}$ & $\%$ & $\begin{array}{l}\text { Kode } \\
\text { isolat }\end{array}$ & $\%$ & $\begin{array}{l}\text { Kode } \\
\text { isolat }\end{array}$ & $\%$ \\
\hline 43 & TP43 & $35,4 a b$ & - & - & - & - & - & - \\
\hline 44 & TP44 & $25,5 \mathrm{~b}$ & - & - & - & - & - & - \\
\hline 45 & TP45 & $80,7 \mathrm{ab}$ & - & - & - & - & - & - \\
\hline 46 & TP46 & $75,0 \mathrm{ab}$ & - & - & - & - & - & - \\
\hline 47 & TP47 & $75,0 \mathrm{ab}$ & - & - & - & - & - & - \\
\hline 48 & TP48 & $80,7 \mathrm{ab}$ & - & - & - & - & - & - \\
\hline 49 & TP49 & $80,0 \mathrm{ab}$ & - & - & - & - & - & - \\
\hline 50 & TP50 & $30,5 a b$ & - & - & - & - & - & - \\
\hline 51 & TP51 & $80,0 \mathrm{ab}$ & - & - & - & - & - & - \\
\hline 52 & TP52 & $85,0 \mathrm{ab}$ & - & - & - & - & - & - \\
\hline 53 & TP53 & $80,0 \mathrm{ab}$ & - & - & - & - & - & - \\
\hline 54 & TP54 & $85,6 \mathrm{ab}$ & - & - & - & - & - & - \\
\hline 55 & K & $0,0 \mathrm{~b}$ & - & - & - & - & - & - \\
\hline
\end{tabular}

* Angka yang diikuti huruf yang sama pada kolom yang sama menunjukkan hasil yang tidak berbeda nyata berdasarkan uji Duncan pada taraf 5\%.

Tabel 3. Keberadaan dan posisi endospora pada isolat bakteri tahan panas terbanyak

\begin{tabular}{cccc}
\hline No & Kode isolat & Ada/tidaknya endospora & Posisi endospora \\
\hline 1 & TP31 & Ada & Dekat ujung \\
2 & TP42 & Ada & Dekat ujung \\
3 & TP48 & Ada & Tengah \\
4 & TP61 & Ada & Tengah \\
5 & TP70 & Ada & Dekat ujung \\
6 & B. subtilis AB89 & Ada & Dekat ujung \\
\hline
\end{tabular}
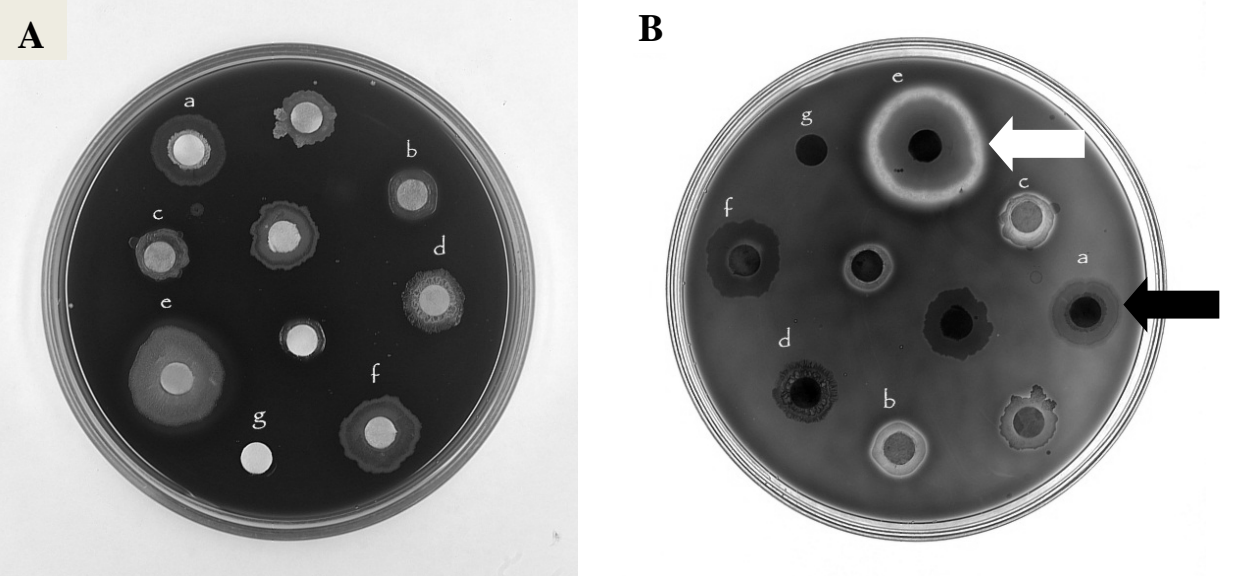

Gambar 4. Reaksi hemolisis pada agar darah isolat bakteri tahan panas terpilih (tampak depan) (A); Reaksi hemolisis pada agar darah isolat bakteri tahan panas terpilih (tampak belakang) (B); a)TP31, b) TP42, c) TP48, d) T61, e) TP70, f) B. subtilis AB89, g) kontrol (LB); $\gamma$-hemolisis (tanda panah hitam), $\beta$-hemolisis (tanda panah putih). 
Tabel 4. Reaksi hemolisis isolat terbanyak kelompok tahan panas pada medium agar darah

\begin{tabular}{cccl}
\hline No & Kode isolat & Sifat lisis & \multicolumn{1}{c}{ Keterangan } \\
\hline 1 & TP31 & $\gamma$-hemolisis & tidak ada perubahan warna \\
2 & TP42 & $\beta$-hemolisis & terlisis sempurna, warna lisis bening \\
3 & TP48 & $\beta$-hemolisis & terlisis sempurna, warna lisis bening \\
4 & TP61 & $\gamma$-hemolisis & tidak ada perubahan warna \\
5 & TP70 & $\beta$-hemolisis & terlisis sempurna, warna lisis bening \\
6 & B. subtilis AB89 & $\beta$-hemolisis & terlisis sempurna, warna lisis bening \\
\hline
\end{tabular}

Hasil uji endospora dan uji pada medium agar darah menunjukkan bahwa isolat TP42, TP48 dan TP70 memiliki kesamaan dengan isolat B. subtilis AB89. Namun berdasarkan morfologi koloni terdapat perbedaan antara isolat TP42, TP48 dan TP70 dengan isolat B. subtilis AB89 (Tabel 5). Hal ini menunjukkan bahwa isolat tersebut diduga bukan merupakan B. subtilis AB89. Isolat-isolat bakteri tersebut merupakan bakteri indigenus yang sudah ada di dalam tanah. Isolat yang memiliki kemiripan morfologi koloni dengan B. subtilis yang diaplikasikan adalah TP32. Isolat TP32 populasinya relatif lebih sedikit dibandingkan dengan kelima isolat tersebut tetapi masih memiliki kemampuan penghambatan in vitro paling tinggi.
Bakteri Fluorescence. Isolat yang banyak ditemukan pada bakteri kelompok fluorescence adalah F3, F4, F7, F9 dan F11. Hasil uji LOPAT menunjukkan bahwa hanya isolat $\mathrm{F9}$ yang berbeda dengan bakteri PGPR yang diaplikasikan (P. fluorescens RH4003). Isolat lainnya menunjukkan karakter yang sama dengan bakteri PGPR yang diaplikasikan (Tabel 6).

Dari hasil semua pengujian karakter pada kelompok fluorescence diketahui bahwa hampir semua isolat bakteri yang diuji menunjukkan karakteristik yang sama dengan bakteri PGPR yang diaplikasikan yaitu $P$. fluorescens RH4003, kecuali isolat F9. Berdasarkan karakter morfologi koloni isolat yang mirip dengan P. fluorescens RH4003 adalah isolat F4 dan F7, yaitu:

Tabel 5. Deskripsi karakter morfologi isolat TP42, TP48, TP70 dan B. subtilis AB89

\begin{tabular}{cccllc}
\hline Kode Isolat & Bentuk & \multicolumn{1}{c}{ Warna } & \multicolumn{1}{c}{ Tepian } & Elevasi & Berlendir/Tidak \\
\hline TP42 & bundar & putih kusam & licin & cembung & tidak \\
TP48 & bundar & putih kusam & berombak & cembung & tidak \\
TP70 & bundar & putih kusam & seperti benang & timbul & tidak \\
B.subtilis AB89 & bundar & putih kusam & berombak & datar & tidak \\
\hline
\end{tabular}

Tabel 6. Hasil uji LOPAT isolat-isolat yang paling banyak ditemukan dalam kelompok fluorescence

\begin{tabular}{|c|c|c|c|c|c|c|}
\hline \multirow{3}{*}{ Kode isolat } & \multicolumn{6}{|c|}{ Uji LOPAT } \\
\hline & \multirow[b]{2}{*}{ Levan } & \multirow[b]{2}{*}{ Oksidase } & \multirow{2}{*}{$\begin{array}{l}\text { Potato } \\
\text { Soft rot }\end{array}$} & \multicolumn{2}{|c|}{ Arginin } & \multirow{2}{*}{$\begin{array}{c}\text { Tobacco } \\
\text { hypersensitive } \\
\text { (HR) }\end{array}$} \\
\hline & & & & $\begin{array}{l}\text { Non- } \\
\text { parafin }\end{array}$ & $\begin{array}{c}\text { Ber- } \\
\text { parafin }\end{array}$ & \\
\hline F3 & + & + & - & + & + & - \\
\hline F4 & + & + & - & + & + & - \\
\hline F7 & + & + & - & + & + & - \\
\hline F9 & - & - & + & - & - & - \\
\hline F11 & + & + & - & + & + & - \\
\hline P. fluorescens RH4003 & + & + & - & + & + & - \\
\hline
\end{tabular}


koloni berbentuk bulat, tepian licin, warna putih susu, elevasi cembung. Isolat F9 memiliki koloni berbentuk bulat, tepian licin, warna putih agak bening, elevasi datar. Semua isolat tersebut menunjukkan fluoresensi (koloni berpendar warna hijau kebiruan) pada medium King's B agar di bawah sinar ultra violet.

Bakteri Kitinolitik. Berdasarkan hasil pengujian diketahui 5 isolat bakteri kitinolitik dengan populasi terbanyak adalah: KT17, KT21, KT29, KT31 dan KT37. Aktivitas kitinolitik ditandai dengan terbentuknya zona bening di sekeliling koloni. Isolat bakteri kitinolitik KT17 mempunyai aktivitas kitinolitik yang sangat kuat ditunjukkan dengan lebar zone bening yang mencapai $2,1 \mathrm{~cm}$. Bakteri penghasil enzim kitinolitik banyak terdapat pada habitat yang memiliki kandungan kitin tinggi, seperti kompos yang mengandung kitin (Sakai et al., 1998), eksoskeleton crustaceae (Vogan et al., 2002), air laut, sedimen laut (Brzezinska \& Donderski 2001) dan dalam tanah (Chernin et al., 1998)

Patil (2004) menyatakan bahwa enzim kitinolitik merupakan enzim ekstraseluler untuk pengambilan nutrisi dan parasitisme. Brzezinska \& Donderski (2001) dan Thompson et al. (2001) menambahkan, bakteri memproduksi enzim kitinolitik untuk mendegradasi kitin sehingga memperoleh $\mathrm{N}$-asetilglukosamin sebagai nutrisi karbon dan nitrogen untuk proses hidup bakteri. Menurut Metcalfe et al. (2002), peranan bakteri kitinolitik penting dalam mempertahankan siklus karbon dan nitrogen dari degradasi kitin dalam ekosistem. Hasil isolasi kelompok bakteri ini dapat dijadikan koleksi untuk kemudian dapat dijadikan calon agens antagonis untuk penyakit-penyakit pada kedelai.

\section{SIMPULAN}

Penanaman varietas Gepak Kuning dengan mulsa dan aplikasi PGPR ternyata dapat meningkatkan kelimpahan bakteri rizosfer pada tanaman kedelai. Perlakuan yang diaplikasikan dalam sistem penanaman relatif lebih berpengaruh terhadap kelimpahan bakteri kitinolitik dan fluorescence dibandingkan dengan bakteri tahan panas dan non-fluorescence. Sebanyak 17 isolat bakteri (TP19, TP21, TP32, TP34, TP35, TP37, TP40, TP45, TP49, TP51, TP52, TP53, TP54, NF10, NF11, KT4 dan KT15) yang berhasil diisolasi dari rizosfer kedelai mampu menghambat pertumbuhan miselia cendawan S. rolfsii secara in vitro lebih dari $80 \%$, sehingga berpotensi untuk menjadi agen biokontrol.

\section{SANWACANA}

Penelitian ini merupakan bagian dari kegiatan penelitian IMHERE B2C-IPB Tahun 2010 dengan judul kegiatan "Penelitian Komponen dan Teknologi Penunjang Pelaksanaan Pengendalian Hama Terpadu Biointensif”.

\section{DAFTAR PUSTAKA}

Arwiyanto T, Sudarmadi, \& Hartana I. 1999. Deteksi strain Pseudomonas solanacearum penghasil bakteriosin. J. Perlintan Indonesia. 2(2): 6065.

Atlas RM. 2005. Handbook of Media for Environmental Microbiology, $2^{\text {nd }}$ Edition. USA: CRC Press.

Baker KF \& Cook RJ. 1983. Biological Control of Plant Pathogen. Freeman and Co, San Fransisco, California.

Bolan NS. 1991. A critical review of the role of mycorrhizae fungi in the uptake of phosphorus by plants. J. Plant and Soil 134: 189-207.

Brzezinska MS \& Donderski W. 2001. Occurance and activity of the chitinolytic bacteria of Aeromonas genus. Polish J. Enviro Studies 10(1): 27-31.

Chernin LS, Michael KW, Jacquelyn MT, Shoshan H, Barrie WB, Cheat W, Gordon SAB, \& Stewart. 1998. Chitinolytic activity in Chromobacterium violaceum. J. Bacteriol. 180: 4435-4441.

Compant S, Duffy B, Nowak J, Clement C, \& Barka EA. 2005. Mini review: Use of plant growthpromoting rhizobacteria for biocontrol of plant diseases: principles, mecanisms of action and future prospects. Appl. Environ. Microbiol. 71: 4951-4959.

Ganesan S, Kuppusamy RG, \& Sekar R. 2007. Integrated management of stem rot disease (Sclerotium rolfsii) of groundnut (Arachis hypogaea L.) using rhizobium and Trichoderma harzianum (ITCC-4572). Turk. J. Agric. For. 31(2): 103-108.

Gao JMW, Bauer KR, Shockley MA, Pysz RM., \& Kelly. 2003. Growth of Hiperthermophilic Archaeon Pyrococcus furiosus on Chitin Involves Two Family 18 Chitinases. J. Appl. Environ Microbiol. 69: 319-328. 
Graham J. 2005. Biological Control of Soilborne Plant Pathogens and Nematodes $2^{\text {nd }}$ Ed. Pearson Education Inc.New Jersey.

Mariani. 1995. Isolasi dan seleksi bakteri filosfer yang berpotensi untuk biokontrol Xanthomonas campestris pv. glycines $8 \mathrm{Ra}$ pada tanaman kedelai dengan esei nukleasi es. Bogor: Jurusan Biologi, Fakultas MIPA IPB.

Metcalfe AC, Krsek M, Gooday GW, Prosser JI, \& Wellington EM. 2002. Molecular analysis of a bacterial chitinolytic community in an upland pasture. J. Appl. Environ. Microbiol. 68(10): 5042-5050.

Mishra DS, Gupta AK, Prajapati CR, \& Singh US. 2011. Combination of fungal and bacterial antagonists for management of root and stem rot disease of soybean. Pak. J. Bot. 43(5): 2569-2574.

Nawangsih AA. 2006. Seleksi dan karakterisasi bakteri biokontrol untuk mengendalikan penyakit layu bakteri (Ralstonia solanacearum) pada tomat. [Disertasi]. Program Pascasarjana, Institut Pertanian Bogor, Bogor.

Oke DO \& Ologun. 2005. Effect of mulch from four agroforestry species on the moisture content, temperature and microbial population in a humid tropical soil. J. Microbiol Scie 5(3): 326-329.

Paramageetham CH \& Babu GP. 2012. Antagonistic activity of fluorescent Pseudomonads against a polyphagous soil borne plant pathogen Sclerotium rolfsii. 1(9): 436. Doi:10.4172/ scientificreports. 436 .

Patil NN, Nawani NN, Thakkar AP, \& Kapadnis BP. 2004: Diversity of chitinolytic systems of bacteria. In: Biotechnological approaches for sustainable development. India: Allied Publishers.

Pelczar MJJr \& Chan ECS. 1986. Dasar-dasar Mikrobiologi. Volume ke-1,2. Hadioetomo RS, Imas T, Tjitrosomo SS, Angka SL, penerjemah. Jakarta :UI Pr; 1986. Terjemahan dari: Elements of Microbiology.

Pleban S, Chemin L, \& Chet I. 1997. Chitinolytic activity of an endophytic strain of Bacillus cereus. Lett. J. Appl. Microbiol. 25(4): 284-288.
Sakai K, Yokota A, Kurokawa H, Wakayama M, \& Moriguchi M. 1998. Purification and characterization of three thermostable endochitinases of a noble Bacillus strain, $\mathrm{MH}-1$, isolated from chitin-containing compost. Appl. Environ. Microbiol. 64(9): 3397-3402.

Salle AJ. 1973. Fundamental Principles of Bacteriology. $7^{\text {th }}$ edition. Tata McGraw-Hill Publishing Company. New Delhi.

Schaad NW. 2001. Laboratory Guide for Identification of Plant Pathogenic Bacteria $3^{\text {rd }}$ Ed. Minnesota: APS Press. St. Paul.

Sudjono MS. 1997. Karakteristik Mikroba Penghasil Kitinase dan Kloning Gen Kitinase dan gen Cry dari Mikroba di Indonesia. Balai Penelitian Bioteknologi Tanaman Pangan.Bogor.

Thompson SE, Smith M, Wilkinson MC, \& Peek K. 2001. Identification and characterization of a chitinase antigen from Pseudomonas aeruginosa strain 385. Appl. Environ. Microbiol. 67(9): 4001-4008.

Vogan CL, Costa RC, \& Rowley AF. 2002. Shell disease syndrome in the edible crab, cancer pagurus isolation, characterization and pathogenicity of chitinolytic bacteria. J. Microbiol. 148: 743-754.

Wang SL \& Chang WT. 1997. Purification and characterization of two bifunctional chitinases/ lisozymes extracellularly produced by Pseudomonas aeruginosa K-187 in shrimp and scrab shell powder medium. Appl. Environ. Microbiol. 63(2): 380-386.

Wartono. 2010. Studi Keefektifan Formulasi Spora Bacillus subtilis sebagai Agens Pengendali Hayati Penyakit Hawar Daun Bakteri dan Hawar Pelepah Serta Pemicu Pertumbuhan pada Tanaman Padi [Tesis]. Program Pascasarjana, Institut Pertanian Bogor, Bogor.

Wu ML, Chuang YC, Chen JP, Chen CS, \& Chang MC. 2001. Identification and characterization of the three chitin-binding domains within the multidomain chitinase Chi92 from Aeromonas hydrophila JP101. Appl. Environ. Microbiol. 67(1): 5100-5106.

Yeh E, Pinsky BA, Banaei N, \& Baron EJ. 2009. Hair sheep blood, citrated or defibrinated, fulfills all requirements of blood agar for diagnostic microbiology laboratory tests. J. Med. 4(7): 6141. 